\title{
Corpus callosum infarction presenting with anarchic hand syndrome
}

\author{
Karim Mahawish
}

Department of Older Persons Rehabilitation Services, Rotorua Hospital, Rotorua, New Zealand

Correspondence to Dr Karim Mahawish, kmahawish@doctors.org.uk

Accepted 31 May 2016

\section{DESCRIPTION}

A 58-year-old woman with a history of poorly controlled type 2 diabetes, hypertension and smoking presented with a left hemiparesis (grade 4/5). Admission glucose was $22.6 \mathrm{mmol} / \mathrm{L}$. MRI of the brain demonstrated an area of restricted diffusion involving the corpus callosum of the left hemisphere (figures 1 and 2). Investigations into the cause of her stroke including vasculitic and thrombophilic causes, echocardiogram, telemetry and carotid Doppler, did not demonstrate any significant pathology. Rather alarmingly, the patient's glycated hemoglobin was elevated at $134 \mathrm{mmol} / \mathrm{mol}$.

During her rehabilitation, further difficulties were identified. Cognitive impairment was identified (Montreal Cognitive Assessment (MOCA) score 10/30), with deficits affecting all categories. As the power in the patient's left arm improved, she described unintended purposeful autonomous movements of her left arm and intermanual conflict, whereby her left hand would undo whatever act her right hand had voluntarily completed, for

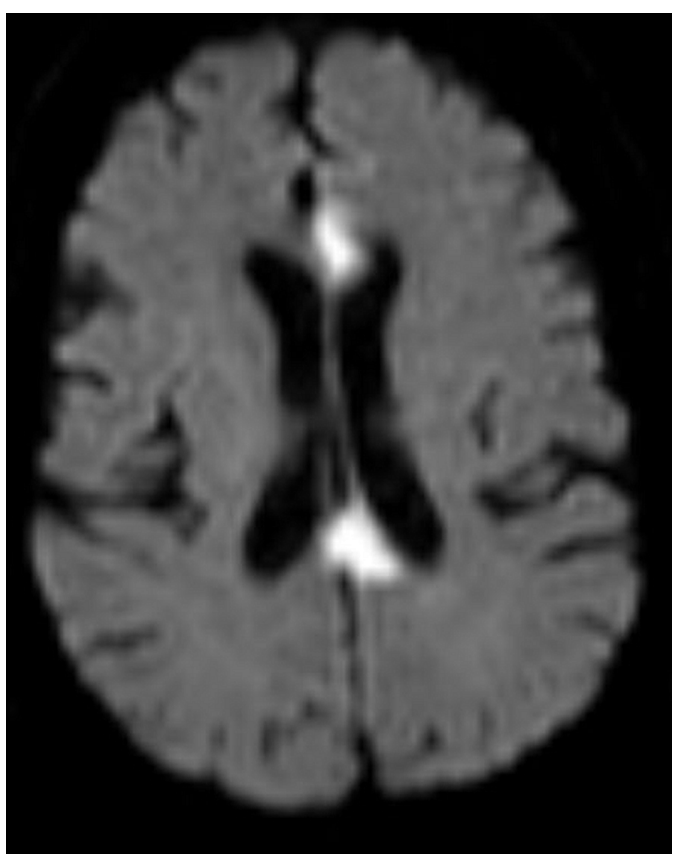

To cite: Mahawish K. BM Case Rep Published online: [please include Day Month Year] doi:10.1136/bcr-2016216071
CrossMark

Figure 1 Axial MR diffusion-weighted imaging sequence showing restricted diffusion affecting the genu and splenium of the corpus callosum. example, when opening a cupboard door with her right hand, her left hand would close it again. This phenomenon has also been termed the 'anarchic hand syndrome'. These experiences were intermittent and occasional, and therefore did not detract from the patient's rehabilitation.

At follow-up 2 months later, her cognition was continuing to improve (MOCA score 21/30), though the involuntary movements continued.

Infarctions of the corpus callosal are rare due to its vascular supply originating from the anterior cerebral and posterior cerebral arteries. In one case series, the corpus callosum was affected in $3.6 \%$ of all patients with stroke. ${ }^{1}$ Causes are vascular in almost half the cases, and include the usual risk factors as well as vasculitis and hypercoagulable states; non-vascular causes including trauma, tumour and demyelination account for the remainder. $^{2}$

In this patient, the traditional risk factors described above were aggressively managed and antiplatelet medication was prescribed.

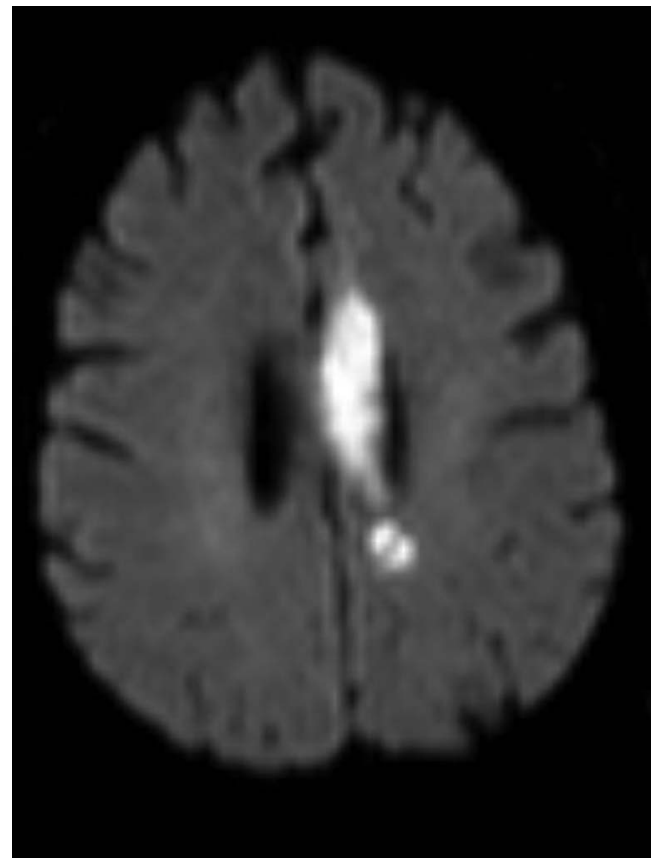

Figure 2 Axial MR diffusion-weighted imaging demonstrating restricted diffusion affecting the body of the corpus callosum. 


\section{Learning points}

- Corpus callosal infarctions are rare and their symptoms wide-ranging. These include hemiparesis, dysphasia and altered consciousness as well as anarchic/alien hand syndrome.

- A 'stroke' affecting the corpus callosum should prompt a thorough assessment for alternative causes, for example, inflammatory, vasculitis, malignancy, etc, as traditional risk factors account for $35 \%$ of all cases. ${ }^{2}$ Further investigations in this patient were not indicated since her risk factors, clinical course and investigation findings suggested an atherosclerotic pathophysiology.
Competing interests None declared.

Patient consent Obtained.

Provenance and peer review Not commissioned; externally peer reviewed.

\section{REFERENCES}

1 Li S, Sun X, Bai YM, et al. Infarction of the corpus callosum: a retrospective clinica investigation. PLOS ONE 2015;10:e0120409.

2 Wilson CA, Mullen MT, Jackson BP, et al. Etiology of corpus callosum lesions with restricted diffusion. Clin Neuroradiol 2015; doi:10.1007/s00062-015-0409-8

Copyright 2016 BMJ Publishing Group. All rights reserved. For permission to reuse any of this content visit http://group.bmj.com/group/rights-licensing/permissions.

BMJ Case Report Fellows may re-use this article for personal use and teaching without any further permission.

Become a Fellow of BMJ Case Reports today and you can:

- Submit as many cases as you like

- Enjoy fast sympathetic peer review and rapid publication of accepted articles

- Access all the published articles

- Re-use any of the published material for personal use and teaching without further permission

For information on Institutional Fellowships contact consortiasales@bmjgroup.com

Visit casereports.bmj.com for more articles like this and to become a Fellow 